To arrive at a proper evaluation of the drugs so far as the splenic enlargement is concerned, a statistical analysis was made of those subjects who had an enlarged spleen at the beginning of the experiment and those who had no such enlargement. The results in the former are similar to the overall figures shown above. In the latter, whose spleen was initially not palpable, all the treated groups showed prevention of splenic enlargement in varying degrees (see Table $\mathrm{XI})$.

TABLE XI.-Showing the Effect of the Drugs on the Spleen of Patients who had no Initial Splenic Enlargement

\begin{tabular}{c|c|c|c|c}
\hline Group & \multicolumn{2}{|c|}{$1948-9$ Experiment } & \multicolumn{2}{|c}{ 1949-50 Experiment } \\
\cline { 2 - 5 } $\begin{array}{c}\text { No. of Cases } \\
\text { with No Palp- } \\
\text { able Spleen } \\
\text { in May, 1948 }\end{array}$ & $\begin{array}{c}\text { Percentage } \\
\text { Showing } \\
\text { Enlargement } \\
\text { in Feb., 1949 }\end{array}$ & $\begin{array}{c}\text { No. of Cases } \\
\text { with No Palp- } \\
\text { able Spleen } \\
\text { in Oct., 1949 }\end{array}$ & $\begin{array}{c}\text { Percentage } \\
\text { Showing } \\
\text { Enlargement } \\
\text { in Feb., 1950 }\end{array}$ \\
\hline I & 73 & 15 & 117 & $11 \cdot 1$ \\
II & 32 & 12 & 130 & 8.5 \\
III & 47 & 0 & 85 & 4.7 \\
IV & 31 & 0 & 90 & $1 \cdot 1$ \\
VI & 56 & 27 & 68 & 67.3 \\
\hline
\end{tabular}

All the treated groups show significantly lower spleen rates compared with the control, in which $27 \%$ developed splenic enlargement after the transmission season. It was striking that in 1948-9 the spleen was not palpably enlarged at the end of the experiment in any of those subjects in the camoquin (III) and chloroquine (IV) groups who had not shown it at the beginning. In 1949-50 the lowest spleen rate was recorded in group IV, and is significantly less than all the other groups except III, which occupies an intermediate position between group IV and other treated groups. It may therefore be concluded that all the prophylactic regimes were effective in preventing splenic enlargement, chloroquine being most valuable in this respect.

\section{Malaria Incidence}

The data for malaria incidence during the prophylactic period were more accurately collected in the second experiment. Nevertheless they should be regarded as only approximate, because there were difficulties in obtaining correct information from the villagers. The incidence rate of malaria in those who were under prophylactic treatment was $21.54 \%$ with bi-weekly proguanil, $12.28 \%$ with weekly proguanil, $3.12 \%$ with camoquin, $2.27 \%$ with chloroquine, and $26.1 \%$ with quinine, as compared with $62.98 \%$ in the control group. It should be mentioned that only parasitepositive cases have been taken in the above analysis, and a person suffering more than once has been counted as one.

We might say that all the treatments were effective in reducing the incidence rate in so far as the rates recorded for these were significantly lower than that of the control group. Group III and group IV treatments were definitely better than all the others. There was no statistical evidence of difference amongst the other treated groups (I, II, and V). The higher rates in groups $I$ and $V$ may have been partly due to the method of collecting the data. These groups were paid two visits a week as compared with one visit in the other groups. This has undoubtedly inflated the figures in groups $I$ and $V$ to some extent. But, even taking this fact into consideration, camoquin and chloroquine show the best results in the prevention of malaria.

\section{Conclusion}

As in chemotherapy, so in chemoprophylaxis, chloroquine (base, $0.25 \mathrm{~g}$. weekly) and camoquin (base, $0.2 \mathrm{~g}$. weekly) have proved superior to proguanil (salt, $0.3 \mathrm{~g}$. weekly or $0.1 \mathrm{~g}$. bi-weekly). They afforded high protection and reduced splenomegaly, thereby improving the general health of the population and increasing the working capacity.

In spite of the fact that the people were living in poor economic conditions, and in the absence of any other antimalarial measures, there was marked reduction in the incidence of malaria, which varied according to the drugs used. Until anti-mosquito measures are possible chemoprophylaxis should have an important place in the suppression of malarial fever. It causes no inconvenience-a dose once or twice a week is enough, and it need not be costly. What is wanted is malaria discipline, but, once impressed, the villagers are willing to co-operate.

We wish to thank Dr. S. Ghosh, Mr. B. N. Dutt, and Mr. C. L. Mitter for their help in this work. Thanks are also due to Imperial Chemical Industries (India) Ltd., Parke, Davis and Co. and the Malaria Department of the National Institute of Health, U.S.A., for the liberal supplies of proguanil and M.5943, camoquin and chloroquine respectively.

\section{REPERENCES}

Curd, F. H. S., Davey, D. G., Hendry, J. A., and Rose, F. L. (1950) Brit. J. Pharmacol., 5. 438.

Davey. D. G. (1946a). Ann. trop. Med. Parasit., 40, 52.

Field (1946b). Ibid., 40, 453.

Field. J. W. (1941). Trans. roy. Soc. trop. Med. Hyg., 35, 35

Jaswant Singh. and Bhattacharji, L. M. (1944). Indian med. Gaz., 79, 102 Spinks, A., and Tottcy, M. M. (1946). Ann. trop. Med. Parasit.. 40. 101

\section{ATYPICAL ABDOMINAL TUBERCULOSIS WITH HAEMATOLOGICAL MANIFESTATIONS}

BY

JOHN FRIEND, M.D., M.R.C.P.

Senior Registrar, Professorial Medical Unit

AND

\section{A. C. THACKRAY, M.A., M.D. Assistant Pathologist \\ The Middlesex Hospital, London}

Enlargement of the liver and spleen is an uncommon mode of presentation of abdominal tuberculosis. The four cases reported below illustrate the clinical appearance of this condition and, in addition, demonstrate the association of blood disorders with hepato-splenic tuberculosis.

\section{Case 1}

A woman aged 69 had had enlarged lymph nodes excised from her neck at the age of 6 years and a tuberculous right axillary lymph node removed when aged 36 . For one year she had suffered from lassitude, haemorrhoids, and an uncomfortable swelling of the abdomen. The cardiovascular, respiratory, and nervous systems were normal. The spleen was hard, painless, and enlarged almost to the umbilicus, with a firm raised swelling $2 \frac{1}{2}$ by $1 \frac{3}{4}$ in. (6.4 by $4.4 \mathrm{~cm}$.) in size palpable on its surface. The liver was enlarged 1-2 in. $(2.5-5 \mathrm{~cm}$.) below the costal 1.targin. She was afebrile and of a steady weight. A blood count on admission showed: $\mathrm{Hb}, 63 \%$ (9.1 g. $\%)$; red cells, $4,500.000$ per c.mm.; white cells, 30,000 per c.mm. (neutrophils $86 \%$, lymphocytes $4 \%$, monocytes $3 \%$, eosinophils $1 \%$, metamyelocytes $2 \%$, myelocytes $4 \%$ ); platelets, 320,000 per c.mm. The blood film revealed hypochromia, microcytosis, and anisocytosis. The sternal marrow gave a total nucleated cell count of 200,000 per c.mm. (myeloblasts $3 \%$, premyelocytes $2 \%$, myelocytes $32 \%$, metamyelocytes $10 \%$, polymorphonuclears $38 \%$, lymphocytes $1.5 \%$, monocytes $0.7 \%$ ). The myeloid/erythroid ratio was $9: 1$. These figures supported the clinical diagnosis of chronic myeloid leukaemia. After a course of deep $x$-ray therapy to the spleen her leucocyte count was 13,500 per c.mm., but rose subsequently to $28,000-50,000$ per c.mm. 
Six months later the patient was readmitted with severe pain in the left loin. She was ill, had lost $6 \mathrm{lb}$. $(2.7 \mathrm{~kg}$.) in weight, and ran a fever up to $102^{\circ} \mathrm{F}$. $\left(38.9^{\circ} \mathrm{C}\right.$.). The spleen reached beyond the umbilicus and was very tender. The liver was enlarged four fingerbreadths below the right costal margin. A blood count showed no anaemia. The leucocyte count was 15,900 per c.mm. (neutrophils $94 \%$, lymphocytes $2 \%$, monocytes $2 \%$, eosinophils $2 \%$ ). One week after admission ascites developed and a left pleural effusion collected shortly before her death.

\section{Post-mortem Examination}

The myocardium was pale and fatty. The left pleural space contained $2 \frac{1}{2}$ pints (1.4 litres) of yellow fluid, with some collapse of the lower lobe of the lung, roughening of the pleural surface, and slender fresh adhesions over the upper lobe. The right lung showed similar but less marked changes. No tuberculosis was found in either lung or in the mediastinal and cervical lymph nodes. The peritoneal cavity contained 7 pints (4 litres) of yellow fluid. The peritoneum and omentum were thickened and studded with white tubercles, chiefly small and discrete but some confluent, and most numerous in the omentum and the visceral peritoneum of the small gut. There were many peritoneal adhesions. The interior of the stomach and intestines appeared normal.

The spleen weighed $52 \mathrm{oz}$. (1.5 kg.), and on its anterior surface close to the tip was a circular mass 2 in. $(5 \mathrm{~cm}$.) in diameter, slightly raised above the surface, consisting of caseous material sharply demarcated by a fibrous capsule. The splenic pulp was soft and the follicular pattern could not be made out. The liver was considerably enlarged and on section was congested and fatty; the gallblacider and bile ducts were normal. There were several caseous lymph nodes up to $\frac{3}{4}$ in. $(1.9 \mathrm{~cm}$.) in diameter grouped around the coeliac axis. The kidneys, suprarenals, and pelvic organs were normal. On splitting the right femur the marrow was seen to be pale pink in colour and soft in consistence, and it extended to the lower end of the bone.

Microscopical Examination.-The omentum contained many tuberculous giant-cell systems, some with caseous centres; occasional tubercle bacilli were found in them. The abdominal lymph nodes contained similar tubercles. In addition, one node contained a large caseous area surrounded by a hyaline fibrous capsule which showed early calcification. There was chronic venous congestion of the liver, which was infiltrated by a moderate number of miliary tubercles consisting of groups of epithelioid cells only, but containing occasional tubercle bacilli. The large mass in the spleen consisted of a structureless granular centre surrounded by a hyaline fibrous capsule. No organisms were found in it. The pulp of the spleen was congested, with hyperplasia of the sinus endothelium and many collections of epithelioid cells. No tubercles were seen in the substance of the lung, but some were present in the pleura. The bone marrow was vascular, few bone trabeculae remaining, and it contained tubercles similar to those in the liver. Haemopoietic cells were reduced in number, most of the cells present being reticulo-endothelial in type, resembling epithelioid rather than primitive myeloid cells.

\section{Case 2}

A man aged 67 had suffered from rheumatic fever when 14 years old ; otherwise his health had been excellent. Early in 1949 he was admitted to hospital with congestive heart failure and auricular fibrillation. The spleen was enlarged and the liver palpable. He was anaemic $(\mathrm{Hb}, 46 \%$; red cells, $3,800,000$ per c.mm.) and had a leucocytosis of 22,000 per c.mm. (polymorphonuclears $80 \%$ ). His heart failure and anaemia responded to treatment. By July, 1949, he had become plethoric and a blood count showed: $\mathrm{Hb}, 130 \%$; red cells, $6,400,000$ per c.mm. ; white cells, 17,400 per c.mm. Venesection was performed repeatedly.
In February, 1950, he suffered again from congestive heart failure and after treatment was transferred to the Middlesex Hospital for radiotherapy for the polycythaemia. He had lost $14 \mathrm{lb}$. $(6.4 \mathrm{~kg}$, $)$ in weight, looked ill, and had a pyrexia of $98-100^{\circ} \mathrm{F}$. $\left(36.7-37.8^{\circ}\right.$ C.). The chest was normal on both clinical and radiological examination. The heart was normal apart from auricular fibrillation and a blowing apical systolic murmur. The spleen, firm and slightly tender, was enlarged almost to the umbilicus, and the liver was palpable three fingerbreadths below the costal margin. Ascites was present. A blood count showed: Hb. $103 \%$; red cells, $6,180,000$ per c.mm.; white cells, 15,600 per c.mm. (86\% polymorphonuclears) ; reticulocytes, $1.4 \%$ : platelets, 600,000 per c.mm. The sternal marrow gave a total nucleated cell count of 49,000 per c.mm. (myeloblasts $0.6 \%$, premyelocytes $3.3 \%$, myelocytes $6 \%$, metamyelocytes $5 \%$, polymorphonuclears $62.3 \%$, lymphocytes $3 \%$, monocytes $7.3 \%$, plasma cells $0.6 \%$ ). The myeloid/erythroid ratio was $7: 1$. The erythroid series was within normal limits and there was an increased number of megakaryocytes. He was thought to suffer from a myeloid leukaemic termination of polycythaemia and was given a diagnostic course of $x$-ray therapy $(800 \mathrm{r})$ to the spleen, without effect upon the leucocytosis, which continued unchanged until his death

\section{Post-mortem Examination}

The heart was enlarged-18 oz. (510 g.)-from hypertrophy of the left ventricle, but was otherwise normal. Both lungs were congested and oedematous, with bilateral pleural effusions. No tuberculous lesions were detected in either lung. The hilar lymph nodes were normal. The peritoneal cavity contained 9 pints (5.1 litres) of blood-stained purulent fluid and there was marked thickening of the peritoneal surfaces, with widespread firm adhesions. The stomach and intestines were normal. The liver weighed $70 \mathrm{oz} .(2 \mathrm{~kg}$.) and its capsule was thickened; on section, it was congested and showed diffusely distributed white deposits of miliary size. The spleen weighed $50 \mathrm{oz}$. $(1.4 \mathrm{~kg}$.) and many nodules varying in size from $\frac{t}{t}$ to $\frac{1}{2}$ in. $(0.3$ to $1.25 \mathrm{~cm}$.) were found in its substance. Most of the nodules were firm, but some were soft and caseous in their centres. The intervening splenic pulp was greyish red in colour and soft. Both kidneys contained simple cysts. The suprarenals, pancreas, and pelvic organs were normal. The abdominal lymph nodes along the aorta and at the root of the mesentery were enlarged, and on section areas of caseation were seen. A film of the peritoneal fluid stained by Gram's method showed numerous pus cells with profuse Gram-positive cocci and Gram-negative bacilli.

Microscopical sections of the abdominal lymph nodes showed numerous tuberculous giant-cell systems with areas of caseous necrosis containing scanty tubercle bacilli. Sections of the spleen showed considerably larger areas of caseation with extensive fibrosis of some of the lesions, but less granulomatous reaction and no tubercle bacilli. In the liver, miliary tubercles were abundant, with very occasional tubercle bacilli in them. The lungs showed congestion and oedema but no tuberculosis.

\section{Case 3}

A man aged 41 complained of lassitude and of pains in the joints for eight days. For five days he had noticed a rash on his skin, initially on the shins but later involving the whole of his body. He was pale and pyrexial-97-99.6 $\mathrm{F}$. $\left(36.1-37.6^{\circ} \mathrm{C}\right.$.). There were no abnormal physical signs. apart from a palpable spleen tip on full inspiration and a widespread skin rash. The rash was macular and ecchymotic, the majority of lesions being surmounted by small pustules. The rash did not fade on pressure, was not tender and was most pronounced on the legs. Hess's test was positive.

A blood count on June 19, 1945, showed: Hb, $49 \%$ (7.1 g. \%) ; white cells, 2,600 per c.mm. (polymorphonuclears $33 \%$, lymphocytes $63 \%$, monocytes $3 \%$, eosinophils $1 \%$ ) ; 
platelets, 350,000 per c.mm. A radiograph of the chest was normal. Serial blood counts showed that the anaemia and leucopenia persisted in the range: $\mathrm{Hb}, 33-49 \%$; red cells, 1,600,000-2,600,000 per c.mm. ; and white cells, 1,4003,700 per c.mm., with an absolute neutropenia and relative lymphocytosis. The sternal marrow gave a total nucleated cell count of 25,000 per c.mm. (polymorphs $11 \%$, metamyelocytes $4 \%$, myelocytes $4 \%$, premyelocytes $2 \%$, myeloblasts $1 \%$, lymphocytes $28 \%$, monocytes $1 \%$, late normoblasts $47 \%$, intermediate normoblasts $2 \%$ ). The myeloid/ erythroid ratio was $0.5: 1$. A diagnosis was not made; the illness progressed steadily, with increasing fever, until the patient died one month after the onset of his symptoms. During the last week of life the spleen became impalpable, although coincidentally the liver enlarged and became tender on palpation.

\section{Post-mortem Examination}

Both pleural spaces contained $5 \mathrm{oz}$. $(140 \mathrm{ml}$.) of yellow fluid. The lungs were voluminous, both lower lobes being solidified by coagulated oedema fluid, with areas suggesting infection of this jelly-like material. The upper lobes were emphysematous, congested, and oedematous. The hilar glands were enlarged and soft. There were no adhesions or free fluid in the peritoneal cavity. The stomach and intestines were normal. The spleen weighed $28 \mathrm{oz}$. (795 g.) and was purple in colour. No Malpighian bodies could be identified, but throughout the pulp were many nodules up to $\frac{1}{8}$ in. $(0.3 \mathrm{~cm}$.) in diameter, firm, and golden yellow in colour. The liver weighed $72 \mathrm{oz}$. ( $2 \mathrm{~kg}$.); the left lobe was represented by fibrous tissue, but the right lobe was enlarged to the iliac fossa. On section there was pronounced mottling, suggesting alternating areas of congestion and fatty change; the gall-bladder and bile ducts were normal. A mass of soft swollen lymph nodes was seen in the upper part of the abdomen around the coeliac axis, individual glands being about $\frac{1}{2}$ in. $(1.25 \mathrm{~cm}$.) in diameter. There was a single large calcified gland in the ileo-caecal mesentery. The other abdominal organs were normal. When the sternum was split it was found to contain red marrow; there was red marrow in the neck and upper third of the shaft of the left femur.

Microscopical Examination.-The abdominal lymph nodes, liver, and spleen contained areas of caseous necrosis surrounded by radially arranged cells resembling fibroblasts and by lymphocytes. No giant cells or typical epithelioid cells were seen, but very large numbers of acid-fast bacilli. were found. The bone marrow was vascular, but haemopoietic cells were scanty and were surrounded by a loose fibroblastic tissue in which were numerous scattered, minute areas of necrosis. Although tubercle bacilli were absent, the lesions were histologically similar to those seen in the liver, spleen. and lymph nodes.

\section{Case 4}

A woman aged 60 complained of a goitre of recent onset and of excessive bruising for some years. Her spleen was palpably enlarged. A blood examination showed: $\mathrm{Hb}, 96 \%$ (13.9 g. \%); red cells, 5,200,000 per c.mm.; white cells, 7,300 per c.mm. (polymorphs $63 \%$, lymphocytes $30 \%$, monocytes $5 \%$, eosinophils $2 \%$ ); platelets, 40,000 per c.mm. (two weeks later they numbered 55,000 per c.mm.); bleeding time, $8 \frac{1}{2}$ minutes (method of Duke); coagulation time, $4 \frac{1}{2}$ minutes (method of Lee and White). Splenectomy was performed without difficulty and the liver appeared normal. Five days later a blood count showed: $\mathrm{Hb}, 81 \%$; red cells, $4,400,000$ per c.mm. ; white cells, 18,500 per c.mm. (polymorphs $85 \%$, lymphocytes $9 \%$, monocytes $6 \%$ ); platelets, 350,000 per c.mm. The patient has remained well and entirely free from purpura since the splenectomy. The spleen was normal in size and weighed $3 \frac{1}{2} \mathrm{oz}$. (100 g.). It was firm but showed no abnormality on its cut surface. Microscopically there was some congestion and fibrosis of the pulp. There were occasional typical small tubercles with caseous centres throughout the organ.

\section{Discussion}

This type of abdominal tuberculosis probably originated in the para-aortic lymph nodes which had been involved in a lymphatic spread of infection from either a mesenteric or an intrathoracic tuberculous gland. The erosion of a caseous para-aortic node into a visceral branch of the abdominal aorta would disseminate the disease to the liver and spleen and to the intestines. The miliary tubercles in the bone marrow (Cases 1 and 3) cannot be regarded as the result of a blood-borne spread of the disease from the liver because of the absence of similar pulmonary lesions (apart from a few tubercles on the pleura in Case 1), and they remain unexplained.

Cases of this variety of abdominal tuberculosis have been reported under many titles (Winternitz, 1912; Fittipaldi, 1938), the most satisfactory being "atypical abdominal tuberculosis," suggested by Blair and Pagel (1947) in describing four unusual pathological types of tuberculosis of the abdomen. Both sexes may be affected at any age, and. unlike the classical forms of the infection, this atypical disease occurs not infrequently in old people, in whom tuberculosis may easily be disregarded as a cause of hepatosplenomegaly.

The disease has usually begun insidiously, most patients complaining of upper abdominal discomfort and swelling. lassitude, and malaise. Marked loss of weight and fever above $100^{\circ} \mathrm{F}$. $\left(37.8^{\circ}\right.$ C. $)$ were uncommon. In a few cases a blood disorder has been the presenting feature, and in a minority the disease ran the rapid course of an abdominal tuberculous septicaemia (Ball et al., 1951). Haematemesis has been recorded rarely as an initial symptom (EngelbrethHolm, 1938; Howells, 1939). The spleen usually reached to, or even beyond, the umbilicus, and was firm, smooth. and often tender, but pain was caused only by infarction. The liver was moderately enlarged, smooth, and slightly tender in most cases. Ascites has been recorded.

When the cause of the hepato-splenomegaly was diagnosed before operation or death it had been suggested by the finding of active extra-abdominal tuberculosis, such as tuberculous lymphadenopathy (Hickling, 1938 ; Coffee and Lipton, 1943), bone and joint tuberculosis (Konstam, 1949), or active pulmonary disease.

Investigations in this disease have been singularly unhelpful. The Mantoux reaction has been of little assistance (Dietz, 1946). Radiographs of the abdomen may assist diagnosis by showing calcification in the spleen (Shands, 1933; Moorman, 1937), liver and spleen (Konstam, 1949 ; Astley and Harrison, 1949), or spleen and mesenteric glands (Solomon and Doran, 1939). Calcification in the lesions has been so uncommon that this method of investigation cannot be relied upon always to yield positive information.

There seems to be no certain method of distinguishing atypical abdominal tuberculosis from the many diseases producing a similar clinical appearance, apart from direct inspection of the abdominal contents. Coyon et al. (1927) performed splenic puncture and recovered tubercle bacilli from the aspirated material by guinea-pig inoculation. Liver puncture biopsy could perhaps be used with less risk (Graddock and Meredith, 1949).

The haemocytopenias associated with tuberculosis of the spleen have been attributed either to splenic or to bonemarrow tuberculosis. Engelbreth-Holm (1938) suggested that the infected spleen exercised an excessive control upon the emission of blood cells from the bone marrow, and Howells (1939), Dietz (1946), and Meredith et al. (1949) reported cases in which a leucopenia was corrected after removal of a tuberculous spleen. Solomon and Doran (1939) and Weiner and Carter (1941) recorded the cure of thrombocytopenic purpura in the same manner. Ball et al. (1951) ascribed the leucopenia of their cases of tuberculous septicaemia, and Gouley et al. (1949) the thrombocytopenia of their case of purpura and tuberculosis, to the tuberculous foci found in the bone marrow. 
The return of the blood cell content to normal after splenectomy may be best explained by assuming hypersplenism, and not marrow tuberculosis, to be the cause of the haemocytopenias; hypersplenism may be excluded only if the blood count fails to respond to splenectomy. Although Ball et al. (1951) found marrow aplasia by sternal puncture in one of their cases, we obtained a normal marrow picture in our Case 3 with leucopenia, and the marrow was hyperplastic in the thrombocytopenic case of Gouley et al. (1949). The last finding is usual in cases of hypersplenism. Marrow tuberculosis is not always associated with a leucopenia, and in Case 1 there was in fact a leukaemoid reaction without anaemia.

The association of leukaemia and tuberculosis is rare, but a leukaemoid blood reaction may occur in the presence of tuberculosis. If the infection causes splenomegaly the simulation of true leukaemia may be perfect, the correct diagnosis being obtained only from a biopsy of the liver or spleen. When the tuberculosis is apparently confined to the abdomen its presence may not even be considered. Similarly, patients suffering from hepato-splenic tuberculosis and polycythaemia vera commonly present with no indication of abdominal tuberculosis. The polycythaemia in such cases was attributed to the splenic tuberculosis by Fitzpatrick and Schwartz (1949) when they reviewed the 36 recorded cases. Splenectomy has not been found to reduce the red blood cell count in these patients, and in Guild and Robson's (1950) case both irradiation of the spleen and its subsequent removal increased the severity of the polycythaemia. The evidence available does not confirm a causal relationship between splenic tuberculosis and polycythaemia.

Atypical abdominal tuberculosis has very rarely been treated with the correct diagnosis previously made. Splenectomy was advised by Winternitz (1912) in order to prevent a spread of the infection from the spleen, but it is improbable that the spleen is the most important focus of the disease, and, in fact, the tuberculosis may progress despite this operation (Frank, 1939). Splenectomy may become necessary, however, to relieve abdominal pressure symptoms or to correct a haemocytopenia.

Streptomycin has been used only twice in the treatment of hepatic or hepato-splenic tuberculosis (Guild and Robson, 1950; Melville. 1951). The results obtained were satisfactory, and at present it seems to be the treatment of choice for this condition.

\section{Summary}

Four cases of atypical abdominal tuberculosis are reported. Post-mortem examinations were made in three cases, all of which demonstrated tuberculosis of abdominal lymph nodes, liver, and spleen. Two of these cases also had miliary tuberculosis of the bone marrow.

One patient showed a leukaemoid reaction; another appeared to have suffered from polycythaemia ; a third, whose illness was rapidly fatal, had a profound neutropenia and anaemia. The last case presented with thrombocytopenia. The relation of these blood disorders to the abdominal tuberculosis is considered.

We wish to thank Dr. G. E. Beaumont, Professor B. W Windeyer, and Mr. C. J. B. Murray for permission to publish notes of their cases; Professor R. W. Scarff, Professor A Kekwick, and Dr. T. Parkinson for their advice and criticism; and Miss W. Cory for her secretarial assistance.

\section{REFERENCES}

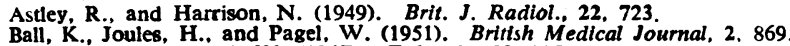
Blair, E. J., and Pagel, W. (1947). Tubercle, 28. 115.

Coffee, H. D., and Lipton, S. (1943). Arch. Surg., Chicago.. 47. 478.

Coyon. A., Clos, W., and Brun, C. (1927). Bull. Soc. med. Hop. Paris, $51,48$.

Dietz, C. R. (1946). Arch. Pediat., 63, 168.

Engelbreth-Holm. J. (1938). A mer. J. med. Sci., 195, 32.

Fittipaldi, C. (1938). Haematologica, 19. 75.96 . Amer. Rev. Tuberc., 60. 660
Frank, T. J. (1939). Roy. Melbourne Hosp. Clin. Rep., 10, 113. Gouley, B. A., Blumberg, N., and Grayson, R. J. (1949). New Engl. J. Med., 241, 147.

Graddock, C. G., and Meredith, H. C., jun. (1949). Ibid., 241, 527

Guild, A. A., and Robson. H. N. (1950). Edin. med. J., 57, 145 .

Hickling, R. A. (1938). Quart. J. Med., 7. 263.

Howells, L. (1939). Brit. J. Tuberc., 33, 178

Konstam. G. (1949). Proc. roy. Soc. Med., 42, 512.

Melville, I. D. (1951). Brit:sh Medical Journal, 1, 1187.

Meredith, H. C., Early, J. Q., and Becker. W. (1949). Blood, 4, 1367

Moorman, L. J. (1937). Amer. Rev. Tuberc., 36, 376.

Shands, H. R. (1933). Amer. J. Surg.. 20, 707.

Solomon, H. A., and Doran, W. T. (1939). N.Y. St. J. Med.. 39. 1288

Weiner, J. J., and Carter, R. F. (1941). Ann. Surg., 113. 57.

Winternitz, M. C. (1912). Arch. intern. Med., 9, 680.

\section{X-RAY APPEARANCES IN ASTHMA A STUDY OF 200 CASES}

BY

HAROLD ROYLE, M.B., B.S.

(From the Allergy Clinic, County Hospital, York)

The object of this investigation was to review the $x$-ray appearances in a series of patients suffering from asthma, together with the clinical findings in the same subjects. in order to find out if $x$-ray appearances could be correlated with clinical types, and to see in what proportion of cases complications occur.

Previous reviews of radiological findings in asthmafor example, Lapage (1922), Manges and Hawley (1927), Bray (1930)-are remarkable for the wide variety of terms used and for the comparatively few films which were regarded as normal. Little effort was apparently made to recognize emphysema, which we know clinically to be such an important and common complication, and segmental collapse was either not seen or not recognized at all.

\section{Present Series}

This series consists of 200 cases of bronchial asthma investigated at an allergy clinic, unselected in any way except that they were divided into two groups, the first consisting of 100 children aged from 14 months to 12 years, the second of 100 adults from 13 to 65 years. Such a division was found convenient, not because I consider that there is any fundamental difference between asthma in childhood and asthma in adult life, but because it is easier to compare films of similar-sized chests, and also because obviously the average duration of the disease will be longer in the older age group.

Table I shows the distribution between the sexes, the family history of allergy, and the average duration of the disease. There is little need to comment on these figures.

TABLE I.-Sex Incidence, Family History, and Average Duration of Disease

\begin{tabular}{|c|c|c|}
\hline & $\begin{array}{l}\text { Children } \\
1-12 \text { Years }\end{array}$ & $\begin{array}{l}\text { Adults } \\
\text { 13-65 Years }\end{array}$ \\
\hline \begin{tabular}{cccc}
\multicolumn{2}{l}{ Total No. of cases } & $\ldots$ & $\ldots$ \\
Males & $\ldots$ & $\ldots$ & $\ldots$ \\
Females & $\cdots$ & $\ldots$ & $\ldots$
\end{tabular} & $\begin{array}{r}100 \\
66 \\
34 \\
\end{array}$ & $\begin{array}{r}100 \\
50 \\
50\end{array}$ \\
\hline 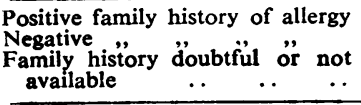 & $\begin{array}{r}66 \\
27 \\
7 \\
\end{array}$ & $\begin{array}{l}58 \\
26 \\
16\end{array}$ \\
\hline Average duration of disease & 3 yrs. 10 mths. & 11 yrs. 10 mths \\
\hline
\end{tabular}

which show the usual preponderance of males over females among the children, and the large proportion with a positive family history of allergy (including asthma, hay-fever. chronic urticaria or dermatoses of allergic type, and migraine). They differ in no important respect from the many other similar series which have been published. 